Egyptian Journal of Aquatic Biology \& Fisheries

Zoology Department, Faculty of Science,

Ain Shams University, Cairo, Egypt.

ISSN $1110-6131$

Vol. 25(3): $607-617$ (2021)

www.ejabf.journals.ekb.eg

\title{
Growth-Promoting and Immunomodulatory Impacts of Commercial Stimulants on Kuruma Shrimp, Penaeus japonicus (Bate, 1888) Juveniles
}

\author{
El-Sayed Hemdan Eissa ${ }^{1}$, Che-Zulkifli C.I ${ }^{2}$, Ashraf A. El-Badawi ${ }^{3-4}$, Mervat A.M. Ali ${ }^{5}$, \\ Baghdady. E.S ${ }^{6}$, Omayma M Abd Al-Kareem ${ }^{7}$, Ragaa A Ahmed ${ }^{6, *}$ \\ 1-Mariculture research Centre, Arish University, Egypt. \\ 2- Crustacean Aquaculture Research Division, Fisheries Research Institute, FRI Pulau Sayak, 08500 Kota \\ Kuala Muda, Kedah, Malaysia. \\ 3- Central Laboratory for Aquaculture Research, Abbassa, Abo- Hammad, Sharkia, Egypt. \\ 4- Biology Department, University College, Umm- Al Qura University, Makkah, Saudia Arabia. \\ 5- Animal Production and Fish Resources Department, Faculty of Agriculture, Suez canal University, \\ Ismailia, Egypt. \\ 6- Department of Aquaculture, Faculty of Fish \& Fisheries Technology, Aswan University, Egypt. \\ 7- Department of Fish Health and Diseases, Faculty of Fish \& Fisheries Technology, Aswan University, \\ Egypt.
}

*Corresponding Author: ragaa10@yahoo.com

\begin{abstract}
ARTICLE INFO Article History:

Received: May 6, 2021

Accepted: May 23, 2021

Online:June 24, 2021

Keywords:

Penaeus japonicas,

Hemolymph,

Hyaline,

Granular cells,

Total hemocyte.
\end{abstract}

\section{ABSTRACT}

A stocking rate of 20 juveniles of healthy Japanese shrimp "Penaeus japonicas", with an average initial body weight of $0.1+0.3 \mathrm{~g}$ and a total body length of $1.4+0.1$ $\mathrm{cm}$, was acclimatized in cultivating fiber glass tanks $(100 \mathrm{~L}$ volume $)$ for ten days. Four diets were created based on the proximate installation of the fodder ingredients (C: control, B: $2.5 \mathrm{~g}$ bactocell, A: $2.5 \mathrm{~g}$ agrimos and BA: $2.5 \mathrm{~g}$ bactocell $+1 \mathrm{~g}$ agrimos)/ kg diet. Shrimps were dispensed into four empirical diets as 3 replicates per each. For sixty days, thrice a day, larvae were fed with experimental diets until satiation. The juveniles were weighed every ten days. Hemolymph was possessed randomly from selected juveniles in each group to determine the total hemocyte (THC), the hyaline cells (HCs), and the granular cells (GCs). The survival of the juveniles fed on BA was significantly high $(\mathrm{P}>0.05)$ compared to the juveniles fed on the other diets. Specific growth rate (SGR) of kuruma shrimp fed on BA and B was significantly higher $(\mathrm{P}>0.05)$ than juveniles fed on other experimental diets. The preferable feed conversion ratio (FCR) was for the juveniles fed on BA diet. The high significant protein productive value (PPV), energy retention (ER), and protein efficiency ratio (PER) were addressed with respect to the juveniles fed on BA. Compared to the control group, a considerable excess was recorded in THC in groups fed on B, A, and BA. The average percentage of GCs for the group fed on A diet was considerably lower than the other juveniles, but no statistically significant variance was detected ( $\mathrm{P}<0.05)$. Notably, the average percentage of total hemolymph count cells in $\mathrm{C}$ group (control group) was considerably lower than that in the other groups $(\mathrm{P}<0.05)$

\section{INTRODUCTION}

The kuruma Marsupenaeus japonicus shrimp is one of the most important economic global species, particularly in Southeast Asia and Taiwan (Cheng et al., 2008; Song Li et 
al., 2010). Regardless of the low level of industry technology in shrimp cultivation, FAO (2018) classified shrimp among the most remarkable species in production and growth performance all over the world, especially in East and South Asia, Latin America, India, and in various inland freshwaters and alkaline environment navigation and coastal marine systems. Recently, shrim aquaculture sector has witnessed significant economic losses due to the spread of diseases in farms (Flegel, 2012). Consequently, a group of chemical treatments such as manufactured antibiotics was used on a large scale in farms to prevent pathogens. However,the continuous use of those manufactured chemicals led to the emergence of what is known as advanced antibiotic resistance, and an accumulation of remnants detected in animal products (Dang et al., 2009; Hoa et al., 2011). Therefore, an alternative treatment is highly required to substitute the use of manufactured antibiotics and chemicals, such as the use of both natural bacteria in probiotics and natural plants to limit the spread of infectious diseases and control the pathogens (Rajasekar et al., 2011).

Probiotics addresses a group of microorganisms that are used as alternative to antibiotic therapy, being a friendly environmental component that contributes increasing aquaculture productivity (Dawood \& Koshio, 2016; Dawood et al., 2016). The microorganism effectively enhances digestibility, promotes growth, raises feed efficiency, and increase the immune response of marine animals (Giorgio et al., 2010; Amaretti et al., 2013; De et al., 2014; Dawood et al., 2015). Remarkably, prebiotics have been used aquaculture, where it has a noticeable effect on increasing growth rates, possibly because it stimulates the appetite of aquatic animals or/ and improves the digestibility. In addition, the probiotics taste should be preferably good and acceptable for the cultured species (Irianto \& Austin, 2002). Rengpipat (2003) found that using Bacillus probiotic (BS11) has significantly increased tiger shrimp's; Penaeus monodon, growing performance and survival ratios. In addition, Liu $(\mathbf{2 0 0 9}, \mathbf{2 0 1 0})$ observed that, the application of $B$. subtilis prebiotic to the white shrimp; Litopenaeus vannamei, may improve growth performance, and increase both vibrio and stress resistances. The organisms that make up probiotics can be applied as a subrogate for antibiotics in the culture of aquatic animals, due to its positive effect on increasing resistance to pathogens, enhancing the immune response, and improving the growth of aqueous animals (FAO, 2002).

The accumulation of wastes in the water of fish culture is an essentially dangerous problem that affects the fish environment owing to its damaging impact on fish survival and production efficiency. Iribarren et al. (2012) decided that one of the most frequently proposed keys in aquaculture is the use of probiotics due to its great effect to solve the problem of excess waste, to increase and improve the growth performance, and reduce the cost of production. Recent studies have shown that different types of probiotics are used to break down the remaining organic material in the feed. Bacteria used for probiotics include Bacillus subtilis, Bacillus licheniformis, and Bacillus megaterium, in addition to the bacteria that reduced the level of ammonium in aquaculture waters and known as nitrification bacteria such as Nitrobacter sp. and Nitrosomonas sp., in addition to the 
bacteria species that are used to maintain the acidity level of the water and to improve the digestive system of shrimp (Bachruddin et al., 2018). Furthermore, Akhter et al. (2015) indicated that the implementation of probiotics showed an improvement in the innate immune system (phagocytes), lysozyme activity, peroxidase and anti-protease activity, as well as in the respiratory system. Noticeably, probiotics have been widely used in aquaculture as important natural substitutions to resist pathogens and improve growth performance in aquatic animals (Senthong, 2012; Reyes-Becerril, 2014). Additionally, Balcazar et al. (2006) reported that, when probiotic-containing organisms are consumed for long periods, they have the ability to form colonies within the digestive system because the rate of occurrence is higher than their death rate, and accordingly, the continuous addition of probiotics to aquaculture farms would enhance those bacteria to adhere to the mucous membrane of the stomach, and hence, a beneficial sphere occurs to the cultured animals. This beneficial practice depends on several elements, such as water temperature, water quality, genetic resistance, enzyme planes, and hydrobionts.

The current study targeted to determine the effect of probiotics and prebiotics on growth performance, body composition, and immune response in Kuruma shrimp, Penaeus japonicus.

\section{MATERIALS AND METHODS}

\section{Experimental Diets}

Four applied diets were prepared based on the proximate conformation of the feed components as follows:

Diet $1 \mathrm{C}=$ control diet containing no prebiotic.

Diet $2 \mathrm{~B}=$ contained $2.5 \mathrm{~g}$ bactocell $/ \mathrm{kg}$ diet.

Diet $4 \mathrm{~A}=2.5 \mathrm{~g}$ agrimos $/ \mathrm{kg}$ diet.

Diet $3 \mathrm{BA}=$ contained $2.5 \mathrm{~g}$ bactocell $+1 \mathrm{~g}$ agrimos $/ \mathrm{kg}$ diet.

Conformation and nearby analysis of the trial diets were performed according to the methods of AOAC, (1990) (Table 1).

\section{Shrimp and experimental system:}

Apparently healthy Japanese shrimps "Penaeus japonicus", with a mean initial body weight of $0.1+0.3 \mathrm{~g}$ and total body length of $1.4+0.1 \mathrm{~cm}$, were stored in rearing fiberglass tanks (100 L volume), with a stocking rate of 20 juveniles for ten days as an acclimatization period. Specimens were fed on a basic trial diet. Then, shrimps were distributed into three experimental treatments as 3 replicates per each. Each tank was provided with an air stone joined with electric compressor for airing the water. Water characteristic parameters were specified, as water temperature was evaluated twice dayto-day (via a thermometer), while water $\mathrm{pH}$, dissolved oxygen, and $\mathrm{NH} 3-\mathrm{N}$ were determined twice day by day. Larvae were fed until satiation thrice a day using the experimental diets for 60 days. The shrimps were weighed every ten days by a 
numerical scale (accurate to $\pm 0.01 \mathrm{~g}$ ) to modify their nurture amount according to the current body weight variations of the shrimps existing in each tank.

\section{Hemolymph sampling for immunological reactions}

Hemolymph was gathered from arbitrarily chosen shrimps in each group to evaluate: total hemocyte (THC), hyaline cells (HCs), semigranular cells (SCs), and granular cells (GCs). The hemolymph $(200 \mu \mathrm{L})$ was extracted from the ventral sinus among the final cephalothorax bit and the first abdominal bit, with a $1.0 \mathrm{~mL}$ needle (26 gauge) prepared with a subcutaneous needle. The needle contained $200 \mu \mathrm{L}$ of a precooled anticoagulant solution (trisodium citrate $27 \mathrm{mM}, \mathrm{NaCl} 336 \mathrm{mM}$, glucose $115 \mathrm{mM}$, ethylenediaminetetraacetic acid $9 \mathrm{mM}, \mathrm{pH}$ 7). The anticoagulant-hemolymph solution (100 microliters) was used to calculate THC, HCs, SCs, and GCs in a Neubauer hemocytometer and reversed phase-contrast microscope. Hemolymph was static with a similar volume of $10 \%$ protected formalin (1:3:5, hemolymph: anticoagulant: formalin ratio) for $20 \mathrm{~min}$, and aliquot $(20 \mu \mathrm{L})$ was stained using hematoxylin and eosin. All hemocytes in equally the top and floor areas of the hemocytometer were totaled. Two hundred cells were totaled to evaluate cell variation. A total of 200 cells were calculated on each slide and total hemocyte cells (THCs) per mL. Different hemocyte cells (DHCs), including large granular cells (LGC), semi-granular cells (SGC), and hyaline cells (HC) were calculated using the successive equations.

$\mathrm{THCs} / \mathrm{mL}=($ cells counted $\times$ dilution factor $\times 1000) /$ volume of grid $(0.1 \mathrm{~mm})^{3}$

DHCs $=$ Number of different hemocyte cell types/ total hemocyte cells counted $\times 100$

\section{Analytical Methods}

At the very beginning, a sample of the examined shrimp (about 30 shrimps) was arbitrarily collected and frozen for initial body chemical conformation. While, at the end of the trial, all shrimps from all treatments were tested to evaluate nearby chemical composition. Samples of the examined feeds and shrimp samples were uncovered to proximate chemical analyses and determine moisture, crude protein (CP), crude lipid, crude fiber, and ash according to the methods of AOAC (1990); for protein (Macro keldahle method), fat (ether extract method) and moisture (over drying).

\section{Statistical Analysis}

Data of the investigated characters (growth performance and feed utilization) were investigated with analysis of variance (ANOVA). The least significant difference test was determined according to Snedecor and Cochran (1989). Hence, the data could be used to determine the maintenance requirements of Kuruma shrimp juveniles (Gatline et al., 1986). The variances within each experimental treatment are assessed using Duncan's Multiple Range Test at $\mathrm{P} \leq 0.05$. During the study, survival (\%) and total length were determined. Survival rates were estimated from the ratio between number of final survivors in each aquarium and the initial stocking rates. 
The growth performance and feed utilization parameters were determined as follows: Weight gain $(\mathrm{WG} ; \mathrm{g})=\mathrm{FW}-\mathrm{IW}$

Specific growth rate (SGR; \%/fish/day) $=100 *[(\mathrm{LnFW})-(\mathrm{LnIW})] /$ experimental days where FW: final fish weight $(\mathrm{g})$; IW: initial fish weight $(\mathrm{g})$

Survival $(\%)=100 *$ [Final number of fish/initial number of fish]

Feed conversion ratio (FCR) based on $\mathrm{DM}=$ feed intake ( $\mathrm{g}$ ) as dry weight/weight gain $(\mathrm{g})$

Feed conversion ratio (FCR) based on $\mathrm{FM}=$ feed intake $(\mathrm{g})$ as fresh matter/weight gain $(\mathrm{g})$

Protein efficiency ratio $(\mathrm{PER})=$ weight gain $(\mathrm{g}) /$ protein intake $(\mathrm{g})$

Protein productive value $(\mathrm{PPV} ; \%)=100 *$ [protein gain $(\mathrm{g}) /$ protein intake $(\mathrm{g})$ ]

Energy Retention $(E R)=$ Retained energy*100/ feed intake

\section{RESULTS}

The goal of the current study is to evaluate the effect of probiotic and prebiotic on growth and production of Kuruma shrimp, Penaeus japonicus.

For water quality parameters (Table 2$)$; no significant difference $(\mathrm{P}<0.05)$ was detected in the concentrations of salinity, temperature, $\mathrm{pH}$, ammonia (NH3) and total ammonia nitrogen (TAN) among treatments during the experimental period. Water turbidity was significantly high for diet BA and A compared to diet C and B.

The initial weight and body weight (BW) gain of kuruma shrimp fed on dietary probiotic (B, A, and BA) are shown in Table (3). Final BW and weight gain increased significantly $(\mathrm{P}>0.05)$ for group fed on $\mathrm{B}$ and $\mathrm{BA}$ after 60 days.

In this study, it was noticed that, the survival rate was significantly $(P>0.05)$ high for the juveniles that was fed on $\mathrm{BA}$ and $\mathrm{B}$, compared to the juveniles fed on the other diets. While, in the juveniles fed on diet $C$ and $A$, no significant differences was allocated between them. Specific growth rate (SGR) of juveniles fed on B, A, and BA was significantly $(\mathrm{P}>0.05)$ higher than juveniles fed on $\mathrm{C}$ diets. The least significant $\mathrm{SGR}$ was for juveniles that fed on $\mathrm{C}$.

The better food conversion ratio FCR (wait/gain) was recorded for those juveniles fed on diet containing $2.5 \mathrm{~g}$ bactocell $+1 \mathrm{~g}$ agrimos / $\mathrm{kg}$ diet (BA), followed by those fed on diet B. The least significant FCR was for juveniles that was fed on C.

The current results revealed that, both ER, PPV, and PER were influenced by various types of probiotic. The high significant PPV and PER were noticed with the juveniles fed on BA and B. For juveniles maintained at C, and A, significantly lower values of PPV and PER were recorded. The energy retention (ER) for juveniles fed on BA was significantly (P> 0.05) high than that of juveniles fed on the other diets. There was no significant variances in ER for juveniles fed on $\mathrm{C}, \mathrm{B}$ or $\mathrm{A}$.

In addition, a significant enhance was observed in the total hemocyte count (THC) in groups B, A, and BA in comparison with the control group (Table 4). The present findings showed that hyaline cells compared to granular cells had the highest rates. On the other hand, results showed that the average percentage of granular cells in group fed on A diet 
was significantly less than the other groups. However, despite the lower average percentage of hyaline cells in agrimos diet compared to the further groups, no significant difference was found $(\mathrm{P}<0.05)$. It is worthy to mention that, the outcomes confirmed that the percentage medium of total hemolymph count cells in $\mathrm{C}$ (control treatment) decreased significantly compared to the other groups $(\mathrm{P}<0.05)$.

For the body composition, it was noted that there are significant differences in the protein, moisture, fat, and ash content of the juvenile's body. The highest total moisture content was achieved by juveniles fed on diet $\mathrm{C}$. Whereas, the highest total protein content was determined for juveniles fed on diet $\mathrm{B}$. There was no significant differences in $\mathrm{CP}$ for juveniles fed on C, A, or BA. Similarly, no significant difference was identified in the content of the total crude fat of juveniles fed on diet B or A, as they achieved a significant increase over the two meals $\mathrm{C}$ and BA. Fish fed on diet B had the significantly lowest total ash content.

\section{DISCUSSION}

In Japan, one of the most important crustacean species is kuruma shrimp (Bulbul $\boldsymbol{e t}$ al., 2014). However, according to FAO (2010), the interest in increasing aquaculture has become the best and safest solution to increase the human share of animal protein and solve the problem of food shortage. In this study, using probiotic in kuruma shrimp diet has guided to significant differences between trial treatments on both growth achievement and food employment, as the use of BA ( $2.5 \mathrm{~g}$ bactocell $+1 \mathrm{~g}$ agrimos/ $\mathrm{kg}$ diet $)$ occasioned the highest WG and SGR followed by B (2.5 g Bactocell), respectively. While, the shrimps fed on control diet achieved a significantly lower WG and SGR. Adel (2017) found that for $L$. vannamei using $L$. lactis subsp. lactis at $108 \mathrm{CFU} \mathrm{g}^{-1}$ can encourage growth performance, activity of digestive enzyme, and disease opposition. Using a probiotic in feeding $M$. japonicus containing $C$. butyricum helps improving growth performance, and as an antioxidant it increases high temperature tolerance and stress resistance (Duan, 2017). Probiotic bacteria plays an important role in improving growth performance, survival ratio, digestibility, resistant response, and disease opposition, as well as the modification of gut commensal microbiota and metabolic syndromes in marine animals. Determination of protein quality, in general, depends on two serious factors: biota value and the competence of use. In the present study, it was noticed that using a mixture of two types of probiotics showed a significant improvement in the use of food. The individuals that were fed B, A, and BA meals showed a significant increase in both PPV, PER, ER, and FCR. Whereas, the individuals that were fed the control diet (free of probiotics) showed a decrease in the indicators of feed utilization.

Hemocytes were investigated to examine the influences of the multispecies probiotic. It's known that part of the inflammatory response decreases the circulating hemocytes (Van de-Braak et al., 2002). In this context, the density of hemocyte blood cells in all treatments 
during this work was significantly increased compared with levels of total hemocyte blood cells in the control group. This occurred due to demolishing the presence of stress due to the lack of immunity or resistance to pathogens.

Hematocytes in shrimps and other crustaceans are nonspecific cellular response that plays a role in the immune reply (Lin \& Söderhäll, 2011). The current results revealed that, , the applying of probiotic to feed led to the peaked THC. This indicates that shrimp given the probiotic had a developed immune restraint compared to the control group that was not provided with the probiotic. Hemocytes involve three kinds of cells depending on the granules in their cytoplasm, i.e. hyaline, granular, and semi granular (Lin \& Söderhäll, 2011). Granular cells play a role in creating and exuding antimicrobial peptides, and are highly concerned in the phagocytosis, encapsulation, early identification, melanisation, and coagulation in some groups (Hauton, 2012). The results of this study showed that hyaline cells compared to granular cells had the highest rates.

With reference to nearby whole-body installation, outcomes of Table (5) indicate that M, CP, CL and CA contents of Kuruma shrimp were significantly $(\mathrm{P}<0.05)$ affected by the various types of probiotic, while content of ash significantly decreased for juvenile fed on diet $\mathrm{B}$ compared to the other experimental diets. The results obtained from this study agree with Barros et al. (2000) and Yildirim et al. (2003), who described that body fat matter is strongly related to weight gain and is in reverse to body moisture content.

\section{CONCLUSION}

The management of probiotics in the shrimp feed could significantly enhance growth performance, body composition, and disease challenge by enhancing immunity response in Kuruma shrimp, Penaeus japonicus, with an optimum dose of $2.5 \mathrm{~g}$ bactocell $+1 \mathrm{~g}$ agrimos/ kg diet.

\section{REFERENCES}

Adel, M.; El-Sayed, A.M. and Yeganeh, S. (2017). Effect of Potential Probiotic Lactococcus lactis Subsp. Lactis on Growth Performance, Intestinal Microbiota, Digestive Enzyme Activities, and Disease Resistance of Litopenaeus vannamei . Probiotics \& Antimicro. Prot., 9: 150-156. doi.org/10.1007/s12602-016-9235-9.

Akhter, N.; Wu, B.; Memon, A. M.; and Mohsin, M. (2015). Probiotics and prebiotics associated with aquaculture. In "A review. Fish and Shellfish Immunology"., 45(2): 733741. doi.org/10.1016/j.fsi.2015.05.038.

Amaretti, A.; Nunzio, M.D.; Pompei, A.; Raimondi, S.; Rossi, M. and Bordoni, A. (2013). Antioxidant properties of potentially probiotic bacteria: in vitro and in vivo activities. Appl. Microbiol. Biotechnol., 97: 809-817. 
AOAC, (1990). Official Methods of Analysis, 15th ed. AOAC International, Arlington, VA, USA.

Bachruddin, M.; Sholichah, M.; Istiqomah, S. and Supriyanto, A. (2018). Effect of probiotic culture water on growth, mortality, and feed conversion ratio of Vaname shrimp (Litopenaeus vannamei Boone). IOP Conf. Series, Earth and Environmental Science., 137: 012-036. DOI: 10.1088/1755-1315/137/1/012036

Balcázar, J.L.; Blas, I.D.; Ruiz, Z. I.; Cunningham, D.; Vendrell, D.; and Múzquiz, J.L. (2006). The role of probiotics in aquaculture. Veterinary Microbiology., 114(3-4): 173-186.

Barros, M. M.; Lim, C.; Evans, J. J. and Klesius, P. H. (2000). Effects of iron supplementation to cottonseed meal diets on growth performance of channel catfish, Ictalurus punctatus. J. Appl. Aquaculture., 10: 65-86.

Bulbul, T.; Ozdemir, V.; Bulbul, A. and Ulutas, E. (2014). The effect of dietary Larginine intake on the level of antibody titer, the relative organ weight and colon motility in broilers. Pol. J. Vet. Sci., 17: 113-121.

Cheng, W.; Tsai, I.H.; Huang, C.J.; Chiang, P.C.; Cheng, C.H. and Yeh. M.S. (2008). Cloning and characterization of hemolymph clottable proteins of kuruma prawn (Marsupenaeus japonicus) and white shrimp (Litopenaeus vannamei). Dev. Comp. Immunol., 32: 265-274.

Dang, H.Y.; Zhao, J.Y.; Song, L.S.; Chen, M.N. and Chang, Y.Q. (2009). Molecular characterizations of chloramphenicol-and oxytetracycline-resistant bacteria and resistance genes in mariculture waters of China, Mar. Pollut. Bull., 58: 987-994.

Dawood, M.A.O. and Koshio, S. (2016). Recent advances in the role of probiotics and prebiotics in carp aquaculture: a review. Aquaculture., 454: 243-251.

Dawood, M.A.O.; Koshio, S.; Ishikawa, M.; El Sabagh, M.A.; Esteban, A.I. and Zaineldin. (2016). Probiotics as an environment-friendly approach to enhance red sea bream, Pagrus major growth, immune response and oxidative status. Fish. Shellfish Immunol., 57: 170-178.

Dawood, M.A.O.; Koshio, S.; Ishikawa, M. and Yokoyama, S. (2015). Effects of heat killed Lactobacillus plantarum (LP20) supplemental diets on growth performance, stress resistance and immune response of red sea bream, Pagrus major. Aquaculture., 442: 2936. 
De, B.C.; Meena, D.K.; Behera, B.K.; Das, P.; Mohapatra, P.K. and Sharma A.P. (2014). Probiotics in fish and shellfish culture: immunomodulatory and ecophysiological responses. Fish. Physiol. Biochem., 40: 921-971.

Duan, Y.; Zhang, Y.; Dong, H. Wang, Y. and Zhang, J. (2017). Effect of the dietary probiotic Clostridium butyricum on growth, intestine antioxidant capacity and resistance to high temperature stress in kuruma shrimp Marsupenaeus japonicus. J Therm Biol., 66: 93-100.

FAO, (2002). Working group report on Drafting Guidelines for the evaluation of probiotics in Food. ftp://ftp.fao.org/es/esn/food/wgreport2.pdf.

FAO, (2018). The State of World Fisheries and Aquaculture 2018. In: "Meeting the Sustainable Development Goals"., Rome, pp. 210-210.

FAO, (2010). The state of world fisheries and aquaculture 2010. Rome, FAO. 197 pp.FAO/ICLARM/IIRR. 2001. Integrated agriculture-aquaculture. In: "a primer. FAO Fisheries Technical Paper"., Rome, pp. 149-407

Flegel, T.W. (2012). Historic emergence, impact and current status of shrimp pathogens in Asia J. Invertebr. Pathol., 110: 166-173.

Gatlin, D. M.; Poe W. E. and Wilson, R. P. (1986). Protein and energy requirements of fingerling channel catfish for maintenance and maximum growth. J. Nutr., 116: 21212131.

Giorgio, G.; Nina, C. and Yantyati, W. (2010). Importance of Lactobacilli in food and feed biotechnology. Res. Microbiol., 161: 480-487

Hauton, C. (2012). The scope of the crustacean immune system for disease control. J. Invertebr Pathol., 110:251-260. https://doi.org/10.1016/j.jip.2012.03.005

Hoa, P.T.; Managaki, S.; Nakada, N.; Takada, H.; Shimizu, A. and Anh, D.H. (2011). Antibiotic contamination and occurrence of antibiotic-resistant bacteria in aquatic environments of northern Vietnam, Sci. Total Environ., 409: 2894-2901.

Irianto, A. and Austin, B. (2002). Probiotics in aquaculture. Journal of Fish Diseases., 25(11):633-642. 
Iribarren, D.; Daga, P.; Moreira, M. T. and Feijoo, G. (2012). Potential environmental effects of probiotics used in aquaculture. Aquaculture International., 20(4):779-789.

Lavens, P. and Sorgeloos, P. (1996). Manual on the production and use of live food for aquaculture. FAO, Rome, Italy.

Lightner, D.V. and Redman, R.M. (1998). Shrimp diseases and current diagnostic methods. Aquaculture., 164(1): 201-220.

Lin, X. and Söderhäll, I. (2011). Crustacean hematopoiesis and the astakine cytokines. Blood., 117: 6417-6424.

Liu, C.H.; Chiu, C.S.; Ho, P.L. and Wang, S.W. (2009). Improvement in the growth performance of white shrimp Litopenaeus vannamei, by a protease-producing probiotic, Bacillus subtilis E20, from natto, J. Appl. Microbiol., 107:1031-1041. https://doi.org/ 10.1111/j.1365-2672.2009.04284.x.

Liu, K.F.; Chiu, C.H.; Shiu, Y.L.; Cheng, W. and Liu, C.H. (2010). Effects of the probiotic, Bacillus subtilis E20, on the survival, development, stress tolerance, and immune status of white shrimp, Litopenaeus vannamei larvae, Fish Shellfish Immunol., 28: 837-844. doi.org/10.1016/j.fsi.2010.01.012.

Lovell, T. (1989). Nutrition and feeding of fish, 3rd Ed. Van Nostrand Reinhold, New York, pp: 163-164.

Rajasekar, T.; Usharani, J.; Sakthivel, M. and Deivasigamani, B. (2011). Immunostimulatory effects of Cardiospermum halicacubum against Vibrio parahaemolyticus on tiger shrimp Penaeus monodon, J. Chem. Pharmaceut. Res., 3: 501513.

Rengpipat, S.; Tunyamum, A.; Fast, A.W.; Piyatiratitivoraku, S. and Menasveta, P. (2003). Enhanced growth and resistance to vibrio challenge in pond-reared black tiger shrimp Penaeus monodon fed a Bacillus probiotic, Dis. Aquat. Org., 55: 169-173 http://doi.org./10.3354/dao055169.

Reyes-Becerril, M.; Ascencio, F.; Gracia-Lopez, V.; Macias, M.E.; Roa, M.C. and Esteban, M.Á. (2014). Single or combined effects of Lactobacillus sakei and inulin on growth, non-specific immunity and $\operatorname{IgM}$ expression in leopard grouper (Mycteroperca rosacea) Fish Physiol. Biochem., 40: 1169-1180. 
Senthong, R.; Chanthachum, S. and Sumpavapol, P. (2012). Screening and identification of probiotic lactic acid bacteria isolated from Poo-Khem, A traditional salted crab. Int. Conf. Nutr. Food Sci., 39: 111-115.

Sequeira, T.; Tavares, D. and Arala-Chaves, M. (1996). Evidence for circulating hemocyte proliferation in the shrimp Penaeus japonicus. Developmental and Comparative Immunology., 20(2): 97-104.

Snedecor, G.; Cochran, W. and Cox, D. (1989). Sta-tistical Methods, 8th edition. The Iowa State University Press.

Song, K.K.; Li, D.F.; Zhang, M.C.; Yang, H.J.; Ruan, L.W. and Xu, X. (2010). Cloning and characterization of three novel WSSV recognizing lectins from shrimp Marsupenaeus japonicus. Fish. Shellfish Immunol., 28: 596-603.

Van- De Braak, C.B.T.; Botterblom, M.H.A. and Taverne, N. (2002). The roles of haemocytes and the lymphoid organ in the clearance of injected Vibrio bacteria in Penaeus monodon shrimp. Fish Shellfish Immunol.,13: 293-309.

Wang, J.; Li, D.; Dong, S.; Wang, K. and Tian, X. (1998). Experimental studies on polyculture in closed shrimp ponds: I. Intensive polyculture of Chinese shrimp (Penaeus chinensis) with tilapia hybrids. Aquaculture., 163: 11-27.

Yildirim, M.; Lim, C.; Wan, P. and Klesius, P. H. (2003). Growth performance and immune response of channel catfish (Ictalurus punctatus) fed diets containing graded levels of gossypol-acetic acid. Aquaculture., 219: 751-768. 